\title{
Soybean Cultivation Technology Package on Tidal Swamp Lands in Indonesia
}

\author{
Arief Harsono ${ }^{1}$, Dian A. A. Elisabeth ${ }^{1}$, Sriwahyuni Indiati ${ }^{1}$, Fachrur Rozi ${ }^{1}$, \\ Didik Harnowo ${ }^{1}$, Titik Sundari ${ }^{1}$, Yudi Widodo ${ }^{1}$, Ruly Krisdiana ${ }^{1}$ \\ and Made J. Mejaya ${ }^{1^{*}}$
}

${ }^{1}$ Indonesian Legumes and Tuber Crops Research Institute (ILETRI), Jl. Raya Kendalpayak km.8, P.O.Box 66 Malang 65101, East Java, Indonesia.

Authors' contributions

This work was carried out in collaboration among all authors. Authors AH, DAAE, FR, DH and TS designed the study. Authors AH, DAAE, FR, DH and MJM performed the statistical analysis and wrote the protocol. Authors AH, DH, SWI and MJM wrote the first draft of the manuscript. Authors AH, FR,

$D H, S W I, T S$ and MJM managed the analyses of the study. Authors AH, DAAE, FR, DH and MJM managed the literature searches. All authors read and approved the final manuscript.

Article Information

DOI: $10.9734 / A R R B / 2021 / v 36 i 730398$ Editor(s):

(1) Dr Paola Angelini, University of Perugia, Italy.

Reviewers:

(1) Abdulraheem Mukhtar Iderawumi, Oyo State College of Education, Nigeria.

(2) Branislav R. Tanasic, University of the People, Serbia, Complete Peer review History: https://www.sdiarticle4.com/review-history/70930

Original Research Article

Received 05 May 2021

Accepted 12 July 2021

Published 21 July 2021

\begin{abstract}
The main constraints of the tidal swamp lands in Indonesia for soybean growth are low soil $\mathrm{pH}$, high Al saturation, and low nutrient availability of $\mathrm{N}, \mathrm{P}, \mathrm{K}, \mathrm{Ca}$, and $\mathrm{Mg}$. The objectives of this research were to determine tolerance of several soybean varieties to Al saturation level, and to obtain a technological package for soybean cultivation which was suitable for farmers to adopt on tidal swamp lands. The research consisted of two stages of study. The first stage formulated of technology package, and the second stage evaluated feasibility of the technology package which was formulation from the first stage. The first stage studied the effect of dolomite application (20\% - $30 \%$ of soil Al saturation) on four soybean varieties (Anjasmoro, Panderman, Dega 1, and Demas). The second stage studied the effect of three technological packages: existing technology; watersaturated soybean cultivation (WSC); and alternative technology which was formulated from the results of the first study. In the $30 \%$ of soil $\mathrm{Al}$ saturation condition, the alternative technology package (application of $50 \mathrm{~kg}$ urea $+75 \mathrm{~kg} \mathrm{SP} 36+50 \mathrm{~kg} \mathrm{KCl}+1500 \mathrm{~kg}$ organic fertilizers/ha + rhizobium biofertilizer "Agriosy" $0.25 \mathrm{~kg} / 50 \mathrm{~g}$ seeds/ha) gave soybean yield of $1.78-2.72 \mathrm{t} / \mathrm{ha}$ for all
\end{abstract}

*Corresponding author: E-mail: mmejaya@yahoo.com, madejmejaya@gmail.com; 
of soybean varieties tested. The alternative technology package with Anjasmoro variety provided higher seed yields (2.62 t/ha) compared to the existing technology (2.07 t/ha) and WSC technology package (2.44 t/ha). The alternative technology package gave a profit of $11,595,000$ IRD/ha with $\mathrm{B} / \mathrm{C}$ values of 1.71 which was higer than the existing and WSC technology packages. The alternative technology package was more profitable than the existing technology (current farmer practice) and water-saturated soybean cultivation technology packages.

Keywords: Cultivation; soybean; technological; package; tidal swamp.

\section{INTRODUCTION}

Domestic soybean production in Indonesia is low, and can only full fill about $25-30 \%$ of the national demand, therefore the government imports soybean about 1.8 million ton/year. The problems to achieve soybean self-sufficiency in Indonesia is the narrow harvest area and low productiviry. In Indonesia In Indonesia, soybean harvested area in 2017 only reached 355,000 ha with productivity $1.51 \mathrm{t} / \mathrm{ha}$ [1], while to achieve self-sufficiency a harvest area of 1,700 ha was needed with a productivity of $1.54 \mathrm{t} / \mathrm{ha}$ [2]. Increasing soybean planting area in order to increase soybean production on the optimal lands are hampered by land use change, and land use for other commodities which has a higher economic value than soybeans. Therefore, one of the alternatives to increase soybean planting area is to optimize the suboptimal lands use, including tidal swamplands which is one of the potential ecosystems for future soybean production. There is about 773 thousand ha of tidal swamps in Indonesia available for food crops development, including of soybean. This land is mostly spread on the islands of Kalimantan, Sumatera and Papua [3]. However, this land has not been widely used for soybean cultivation, because their physical and chemical properties of the soil is not suitable for soybeans. Constraints of soybean production on tidal swamp are water saturated in the roots, high pyrite, toxicity of $\mathrm{Al}, \mathrm{Fe}$, and $\mathrm{Mn}$, deficiencies of $\mathrm{N}, \mathrm{P}, \mathrm{K}, \mathrm{Ca}$, and $\mathrm{Mg}[4,5]$. The most relevant soil chemical properties influencing soybean growth on tidal swamps were low soil $\mathrm{pH}$ and high $\mathrm{Al}$ saturation. This can cause decrease nitrogen fixation and nutrients uptake, especially $P$ which is important for cell growth and photosynthesis. The excessive accumulation of $\mathrm{Fe}$ has been linked to oxidative-damage to proteins, lipids, and losses in chlorophyll content, so that the photosynthetic process that is important for growth and crop yields is not optimal $[6,7]$.

Farmers on tidal lands in Indonesia rarely grow soybeans, so they have little experience. The technology applied is usually very simple, including as presented in Table 1, namely minimally soil tillage, given dolomite about 750 $\mathrm{kg} / \mathrm{ha}$ (regardless of $\mathrm{pH}$ level and Al Saturation of the soil), and fertilized around $50 \mathrm{~kg}$ Urea +50 $\mathrm{kg} \mathrm{SP} 36+50 \mathrm{~kg} \mathrm{KCl} / \mathrm{ha}$. With this technology, the soybean yields obtained by farmers is very low. On tidal land in South Kalimantan-Indonesia with soil $\mathrm{pH} 4.40$ and soil $\mathrm{Al}$ saturation $41.36 \%$, soybean varieties Anjasmoro, Panderman and Tanggamus at NPK fertilization of $50 \mathrm{~kg}$ Urea + $75 \mathrm{~kg} \mathrm{SP} 36+50 \mathrm{kgKCl} / \mathrm{ha}$ only yielded $0.13 \mathrm{t} / \mathrm{ha}$, $0.11 \mathrm{t} / \mathrm{ha}$, and $0.19 \mathrm{t} / \mathrm{ha}$. The addition of dolomite to reduce $\mathrm{Al}$ saturation from $41.36 \%$ to $30 \%$, at the same dose of NPK fertilization these three varieties could produce $1.48 \mathrm{t} / \mathrm{ha}, 0.95 \mathrm{t}$.ha, and $1.74 \mathrm{t} / \mathrm{ha}$, respectively [4]. Wijanarko and Taufiq [5] reported that liming can improve the growth and yield of soybeans in tidal swamp of South Kalimantan. The highest yield was obtained when liming at rate equivalent to $10 \%$ of $\mathrm{Al}$ saturation was mixed with soil within $20 \mathrm{~cm}$ depth, and liming by mixing dolomite with soil within $20 \mathrm{~cm}$ depth resulted in $8 \%$ higher plant height compared to that applied on the soil surface. According to Harsono et al. [4] high Al saturation and nutrient problems in soybean plants on tidal swamps in south Kalimantan can be corrected by using dolomite until the Al-dd saturation decreases to around $20 \%$, using of organic fertilizers $1.25 \mathrm{t} / \mathrm{ha}$, bio-fertilizer Agrisoy $0.25 \mathrm{~kg} / 50 \mathrm{~kg}$ seeds, Urea $50 \mathrm{~kg} / \mathrm{ha}$, SP36 75 $\mathrm{kg} / \mathrm{ha}$ and $50 \mathrm{~kg} \mathrm{KCl} / \mathrm{ha}$. With this fertilizations package, soybean yields on tidal swams in South Kalimantan can reach 2.0 t/ha. According to Ghulamahdi et al. [8], soil water management can be applied to reduce pyrite content where the soil is in reductive condition and able to support soybean growth. However response of soybean to saturated condition varied between varieties. The yellow soybean that Tanggamus and Anjasmoro as adaptive varieties, while on black soybean that Cikuray, Ceneng, and Lokal Malang as adaptive varieties under saturated condition on tidal swamps. Malika is a potential variety to develop of soybean production on tidal swamps on B overflow type with high productivity 
and low risk if affected by temporary flooding. The productivity of Malika on saturated soil culture (SSC) was obtained 4.264 ton ha/ha, and on temporary flooding (TF) was obtained 3.230 ton ha/ha [8]. Results of the several research above, indicate that although the physical and chemical properties of tidal swamps are not suitable for soybean cultivation, but with the addition of dolomite and optimal fertilization, as well as good water management, the land has good potential for growing soybean. The objectives of this research were to determine tolerance of several soybean varieties to $\mathrm{Al}$ saturation level and to obtain a technological package for soybean cultivation which was suitable for farmers to adopt on tidal swamp lands.

\section{MATERIALS AND METHODS}

\subsection{Field Site}

The research was conducted during the 2017 planting season in tidal swamps type C, Barito Kuala Regency of South Kalimantan Province, Indonesia.

\subsection{Research Design}

The research consisted of two stages: (1) a plotscale research to formulation of technological package, and (2) evaluate the feasibility of the technological package which was formulated from the first research.
The first study used a split plot design with three replications. The main plot was application of dolomite as soil ameliorant, consisting of: (A) control (without dolomite) (B) dolomite to reduce soils Al-dd saturation up to $30 \%$, and (C) dolomite to reduce soils Al-dd saturation up to $20 \%$. The Subplots are soybean varieties consisting of: (1) Anjasmoro (the most preferred variety for farmers), (2) Panderman (large seeds resistant to falling), (3) Dega (large seeds with short maturity), and (4) Demas (Adaptive acidic soil, small seeds). The experimental plot size was $3 \mathrm{~m} \times 4 \mathrm{~m}$, plants spacing $40 \mathrm{~cm} \times 15 \mathrm{~cm}$ two plants/ hole. Basic fertilizer $50 \mathrm{~kg}$ urea +75 $\mathrm{kg} \mathrm{SP36}+50 \mathrm{~kg} \mathrm{KCl}+1500 \mathrm{~kg}$ organic fertilizer/ha are given 10 days after planting, and at the time of planting using of rhizobium biological biofertilizer "Agriosy" $0.3 \mathrm{~kg} \mathrm{~kg} / 50 \mathrm{~kg}$ seed/ha.

The second study used a randomized block design with three replications. The treatments consisted of three technological packages, namely: (A) Local farmer technology (Existing technology), (B) Water saturated soybean cultivation (WSC) whic is developed by the Bogor Agricultural University in tidal swamps, and (C) Alternative technology whic is formulated from the results of the first study (Table 1). Each treatment was planted on $4 \mathrm{~m} \times 50 \mathrm{~m}$ plot size.

Table 1. Soybean cultivation technology packages evaluated in tidal swamps type C of South Kalimantan

\begin{tabular}{|c|c|c|c|c|}
\hline \multirow{2}{*}{\multicolumn{2}{|c|}{ Input }} & \multicolumn{3}{|c|}{ Technological pakages } \\
\hline & & $\begin{array}{l}\text { Existing Technology } \\
\text { (A) }\end{array}$ & $\begin{array}{l}\text { WaterSaturated } \\
\text { Cultivation (B) }\end{array}$ & $\begin{array}{l}\text { Alternative Technology } \\
\text { (C) }\end{array}$ \\
\hline 1. & Soils tillage & Minimum tillage & Minimum tillage & Minimum tillage \\
\hline 2. & Drainage canel & $\begin{array}{l}\text { Every weidth of bed } 4 \\
\mathrm{~m} \text {, weidth of canal } 25 \\
\mathrm{~cm} \text { and depth } 20 \mathrm{~cm} .\end{array}$ & $\begin{array}{l}\text { Every weidth of bed } \\
4 \mathrm{~m} \text {, weidth of canal } \\
25 \mathrm{~cm} \text { and depth } 60 \\
\mathrm{~cm} \text {. }\end{array}$ & $\begin{array}{l}\text { Every weidth of bed } 4 \mathrm{~m} \text {, } \\
\text { weidth of canal } 25 \mathrm{~cm} \\
\text { and depth } 20 \mathrm{~cm} \text {. }\end{array}$ \\
\hline 3. & Flooded canel & No & $\begin{array}{l}20 \mathrm{~cm} \text { under of } \\
\text { soils surface }\end{array}$ & No \\
\hline 4. & $\begin{array}{l}\text { Pre-growth } \\
\text { herbisides (I/ha) }\end{array}$ & 5 & 5 & 5 \\
\hline 5. & Soybean variety & Anjasmoro & Anjasmoro & Anjasmoro \\
\hline 6. & Plants spacing & $40 \times 15 \mathrm{~cm}, 2$ plants $/$ hole & $\begin{array}{l}40 \times 15 \mathrm{~cm}, 2 \\
\text { plants/hole }\end{array}$ & $40 \times 15 \mathrm{~cm}, 2$ plants $/$ hole \\
\hline 4. & Urea (kg/ha) & $50 \mathrm{~kg}$ & 150 & 50 \\
\hline 5. & SP36 (kg/ha) & $50 \mathrm{~kg}$ & 175 & 75 \\
\hline 6. & $\mathrm{KCl}(\mathrm{kg} / \mathrm{ha})$ & $50 \mathrm{~kg}$ & 75 & 50 \\
\hline 7. & $\begin{array}{l}\text { Organic fertilizer } \\
\text { (kg/ha) }\end{array}$ & 0 & 1000 & 1500 \\
\hline
\end{tabular}




\begin{tabular}{lllll}
\hline \multirow{2}{*}{ Input } & \multicolumn{3}{c}{ Technological pakages } \\
\cline { 3 - 5 } & $\begin{array}{l}\text { Existing Technology } \\
\text { (A) }\end{array}$ & $\begin{array}{l}\text { WaterSaturated } \\
\text { Cultivation (B) }\end{array}$ & $\begin{array}{l}\text { Alternative Technology } \\
\text { (C) }\end{array}$ \\
\hline 8. & $\begin{array}{l}\text { Foliar fertilizer } \\
\text { (liters/ha) }\end{array}$ & 0 & 8 & 0 \\
9. & Dolomite $(\mathrm{kg} / \mathrm{ha})$ & 750 & 1000 & 500 \\
10. & $\begin{array}{l}\text { Rhizobium }(\mathrm{g} / 50 \\
\text { kg of seeds/ha) }\end{array}$ & 0 & 250 & 250 \\
11. & $\begin{array}{l}\text { Pest control } \\
\text { 12. }\end{array}$ & Intensive & & Intensive \\
& control & Intensive & Intensive & \begin{tabular}{l} 
Intensive \\
\hline
\end{tabular}
\end{tabular}

\subsection{Data Analysis}

The data collected includes: soil chemical properties, components of growth and crop yield, as well as costs and income production of the each practisis of cultivation technique package.

The dose of dolomite to reduce saturation of Alexchanged saturation soil to an estimated $20 \%$ and $30 \%$ were determined by using formula of Subandi et al. [9] :

$B D=\{$ Al-dd - exch.saturation -0.20 or 0.30$) x$ CEC Effective $\mathrm{x} Y$

where BD: amount of dolomite that must be given (t/ha);

Al-exch: saturation level of $\mathrm{Al}-\mathrm{exch}$ in the percent for example $40 \%$ is written 0.40 ;

0.20 or 0.30 : desired level of $\mathrm{Al}$-exch saturation.

CEC-Effective: CEC value at the original soil $\mathrm{pH}$ is obtained by summing the base cation $(\mathrm{Ca}, \mathrm{Mg}$, $\mathrm{K}, \mathrm{Na}$ ), $\mathrm{H}$, and $\mathrm{Al}$ which are absorbed on the soils surface complex, or that can be exchanged. Y: Correction factor, the value is 1.51 if it uses dolomite.

\section{RESULTS AND DISCUSSION}

\subsection{Soil Chemical Properties}

The soil on tiidal swamps used for research was classified as acidic soils with a $\mathrm{pH}$ ranging from 5.3 to 6.0, high C-organic and moderate $\mathrm{N}$ nutrient content. Availability of high $\mathrm{P}$ and $\mathrm{K}$, low $\mathrm{Ca}$ and moderate $\mathrm{Mg}$. The CEC effective is classified as moderate, Al-dd saturation was high, Fe and $\mathrm{Mn}$ were classified as very high (Table 2). This condition indicates that even though the soil is acidic, the availability of macro nutrients is sufficient. This is due to before the land used for research, the land was planted with watermelon with a high dose of dolomite, NPK fertilizer and organic fertilizer. However, the Al-dd saturation was still above the tolerance of soybean plants $(20 \%)$, namely $30.76 \%$ at the first research (Formulation of technological package) location and $31.83 \%$ at the second research (Evaluate of the technological package).

\subsection{Formulation of Technological Package}

There was an interaction effect between varieties and the level of soil Al saturation on plant growth, which is expressed in plant height at harvest. This shows that there is a different response among varieties to the level of Al saturation, especially on plant height (Fig. 1). Anjasmoro variety, in the without addition of dolomite condition (Al saturation $31.35 \%$ ), was able to grow the same height compared to the addition of dolomite until the Al saturation decreased to around $30 \%$ and $20 \%$. Panderman and Demas varieties in without addition of dolomite grew shorter than those at $30 \%$ and $20 \%$ Al saturation. However, the plant height of the two varieties at $30 \%$ and $20 \%$ of soil $\mathrm{Al}$ saturation was not different. Meanwhile, the response of Dega 1 variety to $\mathrm{Al}$ saturation level was same as Anjasmoro variety, namely at $31.35 \% \quad \mathrm{Al}$ saturation (without dolomite) growing the same height compared to growth at $30 \%$ and $20 \% \mathrm{Al}$ saturation.

There was an interaction between varieties and level of $\mathrm{Al}$ saturation on number of root nodules. In general, the number of root nodules increased with the reduction of $\mathrm{Al}$ saturation level from $31.35 \%$ to $30 \%$ or $20 \%$, except for Demas and Anjasmoro varieties. At $30 \% \mathrm{Al}$ saturation, Anjasmoro variety was able to produce more nodules than other varieties, even more so than at $20 \%$ of $\mathrm{Al}$ saturation. This is consistent with the growth of plant height (Fig. 1), that Anjasmoro variety is able to grow better at $30 \%$ Al saturation than the other three varieties. 
It is showed that there was a difference in compatibility between the rhizobium inoculant used and the varieties that were inoculated. Rhizobium Agrisoy inoculant had less positive effect on the number of root nodules for Demas variety although the soil $\mathrm{Al}$ saturation was reduced from $31.35 \%$ to about $20 \%$ (Table 3 ).

The leaf chlorophyll index between plants growing at $31.35 \%$ soils $\mathrm{Al}$ saturation and $30 \%$ or $20 \%$ were not different, likewise the chlorophyll index between varieties was not different (Fig. 2). This is due to the plants have grown optimally, which is shown by the plant height which is almost the same between plants that grow on without dolomite (control) with additional dolomite until the soil Al saturation $20 \%$ (Fig. 2). The number of filled pods between the dolomite treatment to reduce $\mathrm{Al}$ saturation from $31.35 \%$ to about $30 \%$ and $20 \%$ did not differ, but there was a tendency that number of pods at $30 \%$ and $20 \%$ soil $\mathrm{Al}$ saturation was higer than $31.35 \%$ of soil $\mathrm{Al}$ saturation.

There was an interaction between the degree of soil Al saturation and varieties on the number of filled pods at harvest (Table 4). Anjasmoro and Dega1 varieties at $31.35 \%$ soil $\mathrm{Al}$ saturation (control) were able to produce the same number of filled pods compared to adding dolomite until the soil $\mathrm{Al}$ saturation decreased to $30 \%$ or $20 \%$. Panderman variety is more responsive to dolomite addition, namely the number of filled pods increases with the addition of dolomite until the Al saturation decreased from $31.35 \%$ to $20-$ $30 \%$. Meanwhile, the Demas variety, which was classified as tolerant of acidic soils, was able to produce the same number of pods both at $31.35 \%$ and $20 \%$ soil Al saturation (Table 4).

In line with plant growth parameters and number of pods filed which has been presented above, soybean seeds yield in tidal swamps was also determined by the interaction between varieties and levels of soil Al saturation (Table 5). The yield of Anjasmoro and Dega1 varieties increased with the addition of dolomite until the soil $\mathrm{Al}$ saturation decreased from $31.35 \%$ to $30 \%$. However addition of dolomite to reduced $\mathrm{Al}$ saturation from $30 \%$ to $20 \%$ did not increase seeds yield. Meanwhile, the Demas and Panderman varieties, although not added with dolomite, at $31.35 \%$ soil $\mathrm{Al}$ saturation were able to produce the same yield compared to addition of dolomite until the soil Al-dd saturation decreased to $20 \%$ (Table 5 ). From this study it can be determined that Anjasmoro, Panderman, Dega 1 and Demas varieties are able to grow well and give optimal seeds yield at tidal swamps with soil Al saturation around of $30 \%$.

\subsection{Evaluation of Technological Packages}

Application of the alternative technological package for soybean cultivation whic is formulated from the first research was able to increase plant height of Anjasmoro soybean variety compared to the existing technology. Meanwhile, between existing and Water Saturated Cultivation (WSC) technology packages, and between WSC and Alternative technology packages, there were no difference in plant height at harvest (Fig. 3). The highest plant growth in the alternative technology package is thought to be caused by the use of rhizobium biofertilizer which increase the root nodules and the addition of $1500 \mathrm{~kg} / \mathrm{ha}$ of organic fertilizer. Meanwhile, the soil organic $\mathrm{N}$ and $\mathrm{C}$ content were low (Table 2).

The water saturated cultivation and alternative technology packages practice was able to increase the number of filled pods per plant and yield per hectare, but the weight of 100 seeds between the three technology packages was not different (Table 6). This is because the weight of 100 seeds is determined more by genetic factors than environmental factors. The same soybean variety will produce seeds with almost the same size (weight of 100 seeds) when planted in the same environment. The WSC and alternative technology packages were able to increase the seed yield by $17 \%$ and $27 \%$, respectively compared with the existing technology packages which yielded $2.07 \mathrm{t} /$ ha of seeds (Table 6).

Application of WSC and alternative technology packages is able to increase net income compared to the existing technology packages. However, implementation of the WSC technology package is less feasible for farmers to abdoption than the existing technology package. This is due to the production cost of WSC technology package $(8,565,000 \mathrm{IRD} / \mathrm{ha})$ is higher than the existing technology package which only reaches $6,545,000 \mathrm{IRD} / \mathrm{ha}$. The high cost of producing the WSC technology package, mainly due to the cost of constructing drainage channels, higher doses of NPK, dolomite fertilizers, and additional organic fertilizers of up to $1000 \mathrm{~kg} / \mathrm{ha}$. Meanwhile, the technology package for alternative of production costs is relatively lower 
than that of the WSC, especially in terms of the construction of drainage channels, NPK fertilizer, and lower dolomite dose. The existing and alternative technology packages were feasible to be adopted by farmers with B/C values of 1.21 and 1.71 , respectively (Table 7 ).

The all technology packages (Existing, WSC and Anternative) were still absorbs quite a lot of labor, namely $59 \%, 52 \%$ and $46 \%$ of the total production cost, respectively. However, the improved technology package is relatively more efficient than the existing technology and WSC in terms of the total use of production costs (Table 7 and Fig. 4). This production cost, in terms the use of labor for each technology package, can be reduced, especially in the planting and harvest costs which are still done manually could be reduced by using of machinary.

Table 2. Soil chemical properties at Wanaraya District, Barito Kuala Regency of South Kalimantan Province

\begin{tabular}{llll}
\hline $\begin{array}{l}\text { Soil chemical } \\
\text { properties }\end{array}$ & $\begin{array}{l}\text { First research } \\
\text { (Formulation of } \\
\text { technology package) }\end{array}$ & $\begin{array}{l}\text { Second research } \\
\text { (Evaluation of } \\
\text { Package Technology) }\end{array}$ & $\begin{array}{l}\text { Optimal } \\
\text { value }\end{array}$ \\
\hline $\mathrm{pH} \mathrm{H} \mathrm{H}_{2} \mathrm{O}$ & 6.00 & 5.30 & $6.60-7.50$ \\
$\mathrm{C} \mathrm{Org}(\%)$ & 4.14 & 4.55 & $2.01-3.00$ \\
$\mathrm{~N}(\%)$ & 3.39 & 0.47 & $0.21-0.50$ \\
$\mathrm{P}_{2} \mathrm{O}_{5}(\mathrm{ppm})$ & 33.80 & 59.70 & $11.00-15.00$ \\
$\mathrm{~K}(\mathrm{me} / 100 \mathrm{~g})$ & 1.62 & 1.13 & $0.40-0.50$ \\
$\mathrm{Na}(\mathrm{me} / 100 \mathrm{~g})$ & 0.55 & 0.90 & $0.40-0.70$ \\
$\mathrm{Ca}(\mathrm{me} / 100 \mathrm{~g})$ & 2.50 & 3.42 & $6.00-10.00$ \\
$\mathrm{Mg}(\mathrm{me} / 100 \mathrm{~g})$ & 1.45 & 2.62 & $1.10-2.00$ \\
$\mathrm{Al} \mathrm{Exch.}(\mathrm{me} / 100 \mathrm{~g})$ & 3.49 & 5.52 & 8.00 \\
$\mathrm{H}-\mathrm{Exch} .(\mathrm{me} / 100 \mathrm{~g})$ & 1.52 & 3.75 & - \\
$\mathrm{CEC} \mathrm{Effective}$ & 11.13 & 17.34 & $17.00-2400$ \\
$\mathrm{Al}-\mathrm{dd} \mathrm{saturation}(\%)$ & 31.35 & 31.83 & $11.00-20.00$ \\
$\mathrm{Fe}(\mathrm{ppm})$ & 6.49 & 6.92 & 4.50 \\
$\mathrm{Mn}(\mathrm{ppm})$ & 2.25 & 3.09 & 1.00 \\
\hline
\end{tabular}

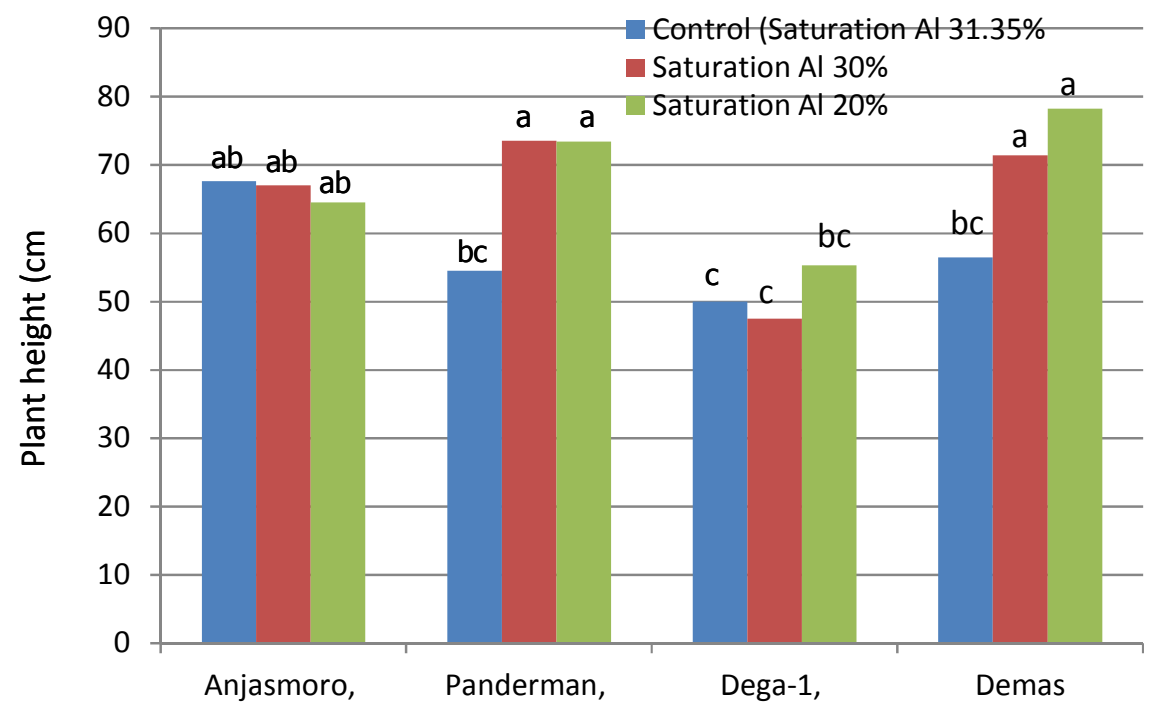

Fig. 1. Plant height of four soybean varieties due to different soil Al saturation at harvesting in Wanaraya District, Barito Kuala Regency of South Kalimantan Province 
Table 3. Number of root nodule/plant of soybean varieties at different Al saturation, Wanaraya District, Barito Kuala Regency of South Kalimantan Province

\begin{tabular}{llll}
\hline Variety & \multicolumn{3}{c}{ Number of root nudule/plant at different Al saturation } \\
\cline { 2 - 4 } & $\mathbf{3 1 . 3 5} \%$ (Control) & $\mathbf{3 0} \%$ & $\mathbf{2 0} \%$ \\
\hline Anjasmoro & $10.70 \mathrm{~g}$ & $42.27 \mathrm{a}$ & $34.93 \mathrm{~b}$ \\
Panderman & $16.67 \mathrm{f}$ & $22.50 \mathrm{e}$ & $27.76 \mathrm{~d}$ \\
Dega-1 & $17.83 \mathrm{f}$ & $30.60 \mathrm{c}$ & $34.83 \mathrm{~b}$ \\
Demas & $18.53 \mathrm{f}$ & $11.76 \mathrm{~g}$ & $17.26 \mathrm{f}$ \\
\hline \multicolumn{4}{c}{ Note: The values followed by the same letter do not different at the $5 \%$ DMRT level. }
\end{tabular}
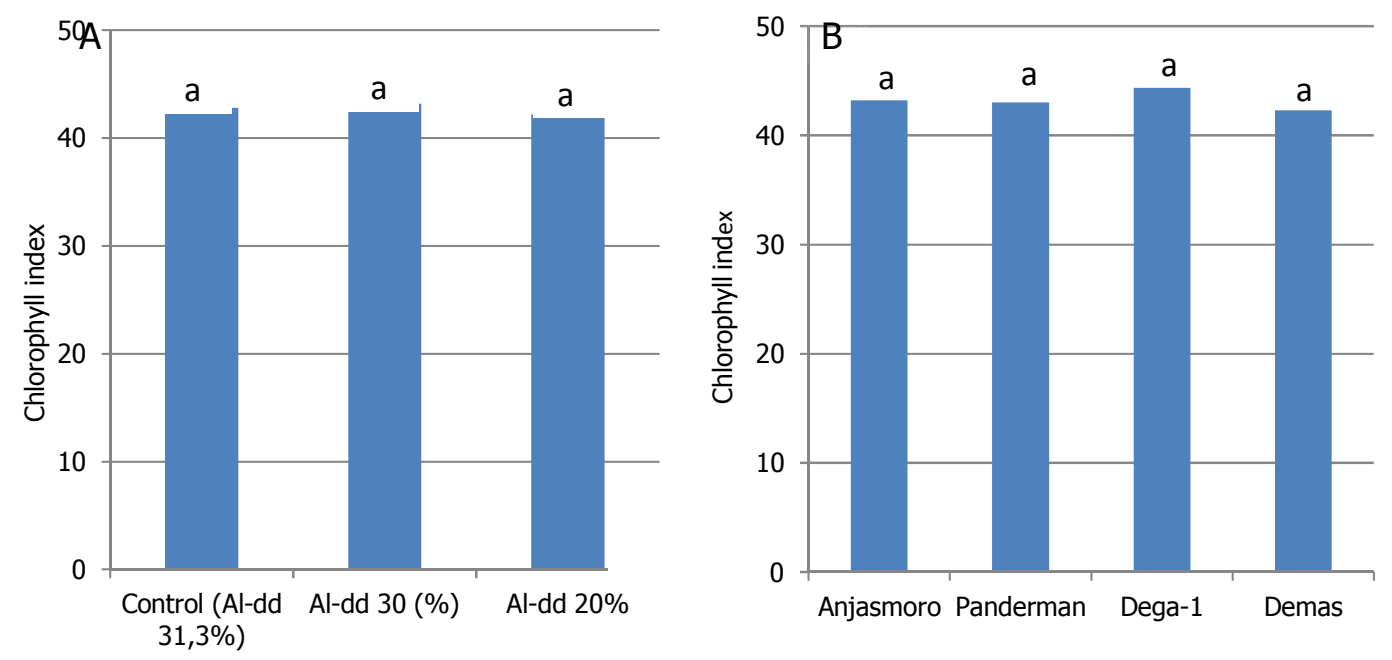

Fig. 2. Chlorophyll index of soybean leaves at different $A$ l saturation $(A)$ and different soybean varieties (B) in Wanaraya District, Barito Kuala Regency of South Kalimantan Province

Table 4. Number of pods filled/plant at different of Al soil saturation and soybean varieties. Wanaraya District, Barito Kuala Regency of South Kalimantan

\begin{tabular}{llll}
\hline Variety & \multicolumn{3}{c}{ Pods filled number/plant at different Al soil saturation levels } \\
\cline { 2 - 4 } & $\mathbf{3 1 . 3 5} \%$ (Control) & $\mathbf{3 0} \%$ & $\mathbf{2 0} \%$ \\
\hline Anjasmoro & $65.67 \mathrm{de}$ & $60.33 \mathrm{def}$ & $73.33 \mathrm{~cd}$ \\
Panderman & $44.67 \mathrm{~g}$ & $58.00 \mathrm{ef}$ & $55.67 \mathrm{efg}$ \\
Dega-1 & $61.00 \mathrm{def}$ & $51.00 \mathrm{fg}$ & $48.00 \mathrm{fg}$ \\
Demas & $88.67 \mathrm{ab}$ & $79.67 \mathrm{bc}$ & $100.00 \mathrm{a}$ \\
\hline \multicolumn{4}{c}{ Note: The values followed by the same letter do not different at the $5 \%$ DMRT level. }
\end{tabular}

Table 5. Soybean seeds yield at different soil Al saturation and soybean varieties, Wanaraya District, Barito Kuala Regency of South Kalimantan Province

\begin{tabular}{llll}
\hline Variety & \multicolumn{3}{c}{ Soybean seeds yield (t/ha) at soil Al saturation } \\
\cline { 2 - 4 } & $\mathbf{3 1 . 3 5 \% ( c o n t r o l )}$ & $\mathbf{3 0} \%$ & $\mathbf{2 0} \%$ \\
\hline Anjasmoro & $1.71 \mathrm{~d}$ & $2.52 \mathrm{a}$ & $2.35 \mathrm{ab}$ \\
Panderman & $1.85 \mathrm{~cd}$ & $2.29 \mathrm{abc}$ & $2.01 \mathrm{bcd}$ \\
Dega-1 & $1.68 \mathrm{~d}$ & $2.72 \mathrm{a}$ & $2.53 \mathrm{a}$ \\
Demas & $1.71 \mathrm{~d}$ & $1.78 \mathrm{~d}$ & $1.95 \mathrm{bcd}$ \\
\hline
\end{tabular}


Note: The values followed by the same letter do not different at the 5\% DMRT level.

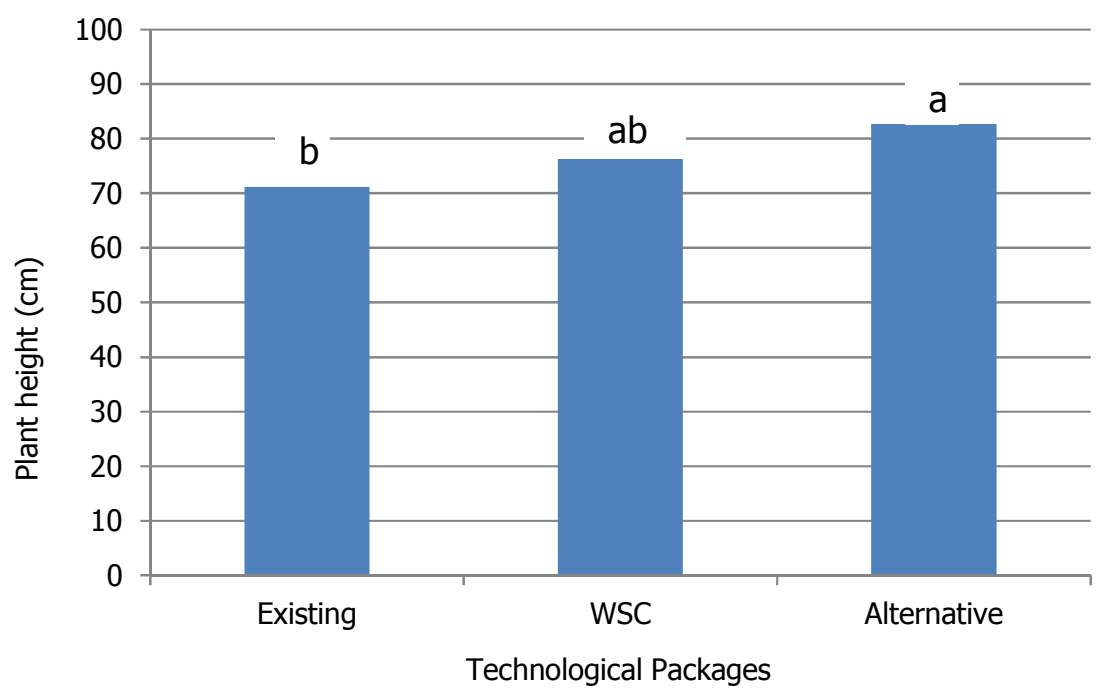

Fig. 3. Plant height at harvest on existing, water-saturated soybean cultivation (WSC), and technology packages, Wanaraya District, Barito Kuala Regency of South Kalimantan Province

Table 6. Number of filled pods and soybean seed yields in different of technological package on tidal swamps. Wanaraya District, Barito Kuala Regency of South Kalimantan

\begin{tabular}{|c|c|c|c|c|}
\hline $\begin{array}{l}\text { Technological } \\
\text { package }\end{array}$ & $\begin{array}{l}\text { Number of filled } \\
\text { pods/plant }\end{array}$ & $\begin{array}{l}100 \text { seeds } \\
\text { weight }(g)\end{array}$ & Seed yield (t/ha) & $\begin{array}{l}\text { Increased } \\
\text { yield (\%) }\end{array}$ \\
\hline Existing & $30.70 \mathrm{~b}$ & $15.52 \mathrm{a}$ & $2.07 \mathrm{a}$ & 100 \\
\hline $\begin{array}{l}\text { Water-saturated } \\
\text { soybean cultivation } \\
\text { (WSC) }\end{array}$ & $34.55 a b$ & $15.40 \mathrm{a}$ & $2.42 \mathrm{~b}$ & 117 \\
\hline Alternative & $40.80 a$ & $15.45 \mathrm{a}$ & $2.62 \mathrm{c}$ & 127 \\
\hline
\end{tabular}

Table 7. Income of soybean cultivation with existing, water-saturated soybean cultivation (WSC) and alternative technological packages, Barito Kuala, South Kalimantan

\begin{tabular}{lllcc}
\hline No & Componens & \multicolumn{3}{c}{ Technological packages } \\
\cline { 3 - 5 } & & Existing & WSC* & Alternativent \\
\hline 1 & Cost production (IRD/ha) & & & \\
& a. Inputs & $2,695,000$ & $4,065,000$ & $2,930,000$ \\
& b. Labour & $3,850,000$ & $4,500,000$ & $3,850,000$ \\
& Cost total (IRD/ha) & $6,545,000$ & $8,565,000$ & $6,780,000$ \\
2 & Seed yield (kg/ha) & 2,067 & 2,422 & 2,625 \\
3 & Total revenue (IRD/ha) & $14,469,000$ & $16,954,000$ & $18,375,000$ \\
4 & Total benefit (IRD/ha) & $7,924,000$ & $8,389,000$ & $11,595,000$ \\
5 & R/C & 2.21 & 1.98 & 2.71 \\
6 & B/C & 1.21 & 0.98 & 1.71 \\
\hline & & &
\end{tabular}




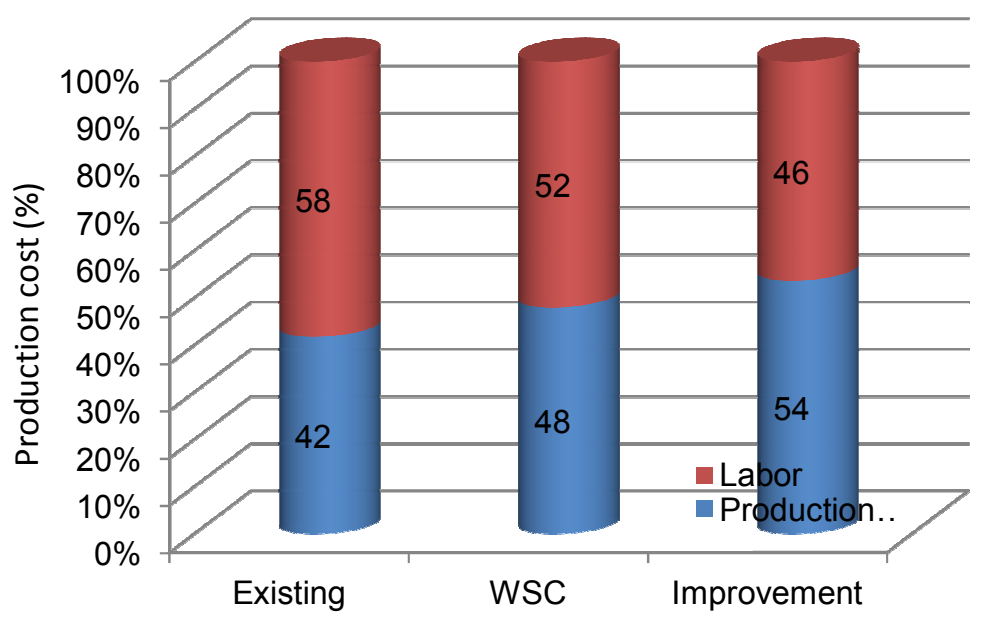

Fig. 4. Composition of soybean production costs on tidal swamps with existing, watersaturated soybean cultivation (WSC), and improvement technologies

Several researchers reported that soil $\mathrm{pH}$ suitable for soybean growth ranges from 6.0 up to 6.5 [10], and plants still can grow optimally at soil $\mathrm{pH}$ of 6.8 with a critical limit of saturation $\mathrm{Al}$ soil $20 \%[11,12]$. According to Subandi et al. [9] formula, in the first research to reduce Al-dd saturation from $31.35 \%$ to $30 \%$ and $20 \%$ an additional of $1420 \mathrm{~kg} / \mathrm{ha}$ and $300 \mathrm{~kg} / \mathrm{ha}$ dolomite is needed, respectively. Meanwhile in the second research, to reduce the Al saturation from $31.83 \%$ to $30 \%$ there was needed dolomite 500 $\mathrm{kg} / \mathrm{ha}$.

Anjasmoro and Dega1 varieties are more adaptive to $\mathrm{Al}$ saturation by around $31.35 \%$ compared to Panderman and Tanggamus varieties. However, at the all saturation levels of Al, Dega variety was grew shorter than Anjasmoro variety. The taller the plant, the plant will be able to produce higher seeds. The more adaptive of Anjasmoro variety to Al saturation, with better plant growth and large seed sizes, it is the main attraction, so that farmers prefer this variety to the Panderman, Dega1, and Demas varieties. According to Krisnawati and Adhie [13], soybean plant height has a positive correlation with soybean yield, in other words, plant height determines the level of yield achieved by plants.

According to Gulamahdi [14], Anjasmoro soybean variety was classified as adaptive in tidal swamps. Meanwhile, for Panderman and Dega 1 varieties, the formation of nodules was more at $20 \%$ Al saturation than growth at higher Al saturation, namely at $30 \%$ or $31.35 \%$ of $\mathrm{Al}$ saturation. For Demas variety which is tolerant for acid soil, at $31.35 \%$ Al soil saturation is able to produce as number of root nodules as it grows at $20 \%$ Al saturation, although the number of nodules is less than Anjasmoro, Panderman, and Dega 1 varieties.

Vollmann et al. [15] reported that root nodules of soybean plants has a positive correlation with size and content chlorophyll leaves, which in turn will affect the rate of photosynthesis and fixation nitrogen, plant height, number of pods per plants, weight of 100 seeds, protein content, and oil content of the seeds. According to Harsono et al. [16], Anjasmoro variety is classified as adaptive to tidal swamps. This variety can be grew at $30 \%$ Al saturation, and produces the same number of filled pods per plant as grew at $20 \%$ Al saturation. In this study, Demas variety produced more filled pods per plant than the other three varieties. This was in accordance with its genetic nature that soybean varieties with small seed sizes generally produced more filled pods than large-seeded soybean varieties.

\section{CONCLUSION}

Anjasmoro, Panderman, Dega1, and Demas varieties on tidal swamps, can grow well at $30 \%$ of soil Al saturation. At this soil Al saturation with applied of $50 \mathrm{~kg}$ urea $+75 \mathrm{~kg} \mathrm{SP} 36+50 \mathrm{~kg} \mathrm{KCl}$ $+1500 \mathrm{~kg}$ organic fertilizers/ha + rhizobium Agriosy 0.25 fertilizer $\mathrm{kg} / 50 \mathrm{~g}$ seeds/ha (Alternative technological package) these four varieties yielded $1.78-2.72 \mathrm{t} / \mathrm{ha}$. The alternative technology package whic was formulated from 
the first research, by using Anjasmoro variety was able to provide higher yields (2.62 t /ha) compared to the existing and water saturated cultivation (WSC) technology packages, which yielded $2.07 \mathrm{t} / \mathrm{ha}$ and $2.44 \mathrm{t} / \mathrm{ha}$. It is feasible for farmers to adopts with a profit of up to $11,595,000$ IRD /ha, with $B / C$ values of 1.71 which was higer compared to existing and WSC technolocal packages.

\section{FUNDING SOURCE}

Ministry of Agriculture Republic of Indonesia DIPA 2017.

\section{ACKNOWLEDGEMENT}

We would like to thank the the Director General of the Indonesian Agency for Research and Development (IAARD) in Jakarta, the Director of the Indonesian Food Crops Research and Development (ICFORD) in Bogor, the Head of the Indonesian Legumes and Tuber Crops Research Institute (ILETRI) in Malang who gave facilities for conducting this research. Thanks to all of supporting stafs that worked hard to make this research done.

\section{COMPETING INTERESTS}

Authors have declared that no competing interests exist.

\section{REFERENCES}

1. Indonesian Agricultural Statistic. Jakarta: Center for agricultural data and information system. Ministry of Agriculture Republic of Indonesia; 2019.

2. Harsono A. Langkah merengkuh swasembada kedelai. Forum komunikasi profesor riset. Ragam pemikiran pengembangan pertanian 2015-2016. Jakarta: Badan Penelitian dan pengembangan pertanian. Kementerian Pertanian Indonesia; 2017.

3. Mulyani A, Nursyamsi D, Harnowo D. Potency and challanges for the use of suboptimal land for development of legumes and tuber crop. in A.A. Rahmianna et al (Ed.). Proceedings of the National Seminar on legumes and tuber crops 2016. Jakarta: Indonesian Agricultural Agency Research and Development; 2017.

4. Harsono A, Sucahyono D, Elisabeth DAA. Soybean cultivation packages applied in young palm oil plantation on tidal land. Buletin Palawija. 2020;18(2):62-73.

Available:https://dx.doi.org/10.21082/bulpa .v18n2.2020.p62-7

5. Wijanarko A, Taufiq A. Effect of lime application on soil properties and soybean yield on tidal land. Agrivita. 2016;38(1): 14-23.

Available:http://doi.org/10.17503/agrivita.v $38 \mathrm{i} 1.683$

6. Alves LA, Ambrosini VG, Denardin LGO, Flores JPM, Martins AP, Filippi D, Bremm C, Paulo C, Carvalho F, Farias GD, Ciampitti IA, Tiecher T. Biological $\mathrm{N}_{2}$ fixation by soybeans grown with or without liming on acid soils in a no-till integrated crop-livestock system. Soil and Tillage Research. 2021;209,104-923.

7. Yu HN, Liu P, Wang ZW, Chen WR, Xu GD. The effect of aluminum treatments on the root growth and cell ultra structure of two soybean genotypes. Crop Protection. 2011;30(3):323-328.

DOI : 10.1016/j.cropro.2010.11.024

8. Ghulamahdi M, Melati, Sagala D. Production of soybean varieties under saturated culture on tidal swamps. J. Agron. Indonesia. 2009;37(3),226-232. Available:https://doi.org/10.24831/jai.v37i3. 1301.

Available:https://journal.ipb.ac.id/index.php /jurnalagronomi/article/view/1301.

9. Subandi, Marwoto, Adisarwanto T, Sudaryono, Kasno A, Hardaningsih S. Panduanumum pengelolaan tanaman terpadu kedelai. Malang: Balitkabi; 2007.

10. Uguru MI, Oyiga BC, Jandong EA. Responses of some soybean genotypes to different soil $\mathrm{pH}$ regimes in two planting season. The Afrian Journal of Plant Science and Biotechnology. 2012;6(1): 26-37.

Available:https://www.zef.de/uploads/tx_ze fportal/Publications/27c6_AJPSB_6(1)2637.pdf

11. Koesrini, Anwar K, Berlian E. Application of Lime and Adaptable Variety to Increase Soybean (Glycine max Merill) Productivity on Actual Acid Sulphate Soil. Berita Biologi.2015;14(2):155-161.

Available:https://media.neliti.com/media/pu blications/53570-ID-none.pdf

12. Wijanarko A, Subandi. Effect of dosage and kinds of organic fertilizer on soybean yield at acid soil. Buletin Palawija. 2017;15(1):45-49. 
Available:File://C:/Users/User/Downloads/ 6050-29817-1-Pb.Pdf

13. Krisnawati A, Adie MM. Relationship between morphological component with seed yield characters of soybean. Buletin Palawija.2016;14(2):49-54.

Available:https://media.neliti.com/media/pu blications/225873hubunganantarkompone n-morfologi-dengan68b7fe69.pdf

14. Ghulamahdi M, Chaerunisa SR, Lubisa I, Taylor P. Response of five soybean varieties under saturated soil culture and temporary flooding on tidal swamp. Procedia Environmental Sciences. 2016; 33:87-93.
DOI: 10.1016/j.proenv.2016.03.060.

15. Vollmann J, Wakter $\mathrm{H}$, Sato $\mathrm{T}$, Schwelger P. Digital image and chlorophyll metering for phenotyping the effect of nodulation in soybean. Computers and Electronics in Agriculture. 2011;75(1): 190-195.

16. Harsono A, Wijanarko A, Lestaril SAD. Productivity of soybean under palm oil plantation on tidal swamps due to several packages of technology. IOP Conf. Series: Earth and Environmenral Science. 2020; 456:1-9. DOI:10.1088/1755-1315/456/1/012052

(c) 2021 Harsono et al.; This is an Open Access article distributed under the terms of the Creative Commons Attribution License (http://creativecommons.org/licenses/by/4.0), which permits unrestricted use, distribution, and reproduction in any medium, provided the original work is properly cited.

Peer-review history:

The peer review history for this paper can be accessed here: https://www.sdiarticle4.com/review-history/70930 